\title{
INCIDENCE OF CONGENITAL HEART DISEASE IN SINGAPORE
}

\author{
BY \\ C. S. MUIR \\ From the Department of Pathology, University of Malaya in Singapore \\ Received June 24, 1959
}

The diagnosis, and in many centres the surgical correction, of congenital heart disease is now commonplace. Several large series, both clinical and post-mortem, reporting the relative incidence of the various cardiac anomalies have now been published. Further, attempts have been made to estimate the absolute incidence of such anomalies in given populations, e.g. McMahon et al. (1953) in Birmingham and Carlgren (1959) in Gothenburg. Such data, in the main, relate to temperate climes, and to persons of Caucasian stock. Elsewhere little attention has been paid to such defects and ". . . there is little published work on the incidence of congenital malformations of the heart in tropical and sub-tropical areas ..." (Williams and Simpkiss, 1958).

This paper describes and classifies, from a morbid anatomical viewpoint, the 411 cases of congenital heart disease seen in 19,415 consecutive unselected necropsies performed at the General Hospital, Singapore, in the decade 1948-57.

\section{Method AND MATERIAL}

The data considered relevant were extracted from the post-mortem protocols and entered on specially prepared forms for subsequent analysis. As 17 per cent of the necropsies in this series were performed at the request of H.M. Coroner on children found dead, and as many of those admitted to the wards died less than four hours after admission, no attempt has been made to record clinical data.

Singapore is a multiracial city. While theoretically one might expect that the post-mortem figures for a particular disease would reflect, by and large, the relative racial frequencies (Chinese $76.5 \%$, Indians $8 \%$, Malays $12 \%$, and others $3.5 \%$ in the 1957 census) in this series of 411 cases, $400(97 \%)$ were of Chinese race, $10(2.4 \%)$ were of Indian stock, and 1 was a Malay, an absolute and relatively overwhelming preponderance of Chinese.

If one examines, by race, the number of necropsies performed in Singapore, there is again an undue relative preponderance of Chinese, as the bodies of many Chinese children dying in hospital are not claimed and come to autopsy, as it were, by default. Further, for religious and other reasons it is much more difficult to obtain permission to examine the bodies of Indians and Malays. Thus, although the data in this paper relate mainly to the Chinese population, it cannot be assumed that the incidence in Chinese is higher than in other races.

The relative incidence of the lesions is shown in Table III. There is no reason to think it is significantly different from that in other parts of the world.

\section{Ventricular SePtal Defect}

A ventricular septal defect (V.S.D.) was found in 95 persons: 54 male (57\%) and 40 female, the sex of the remaining one not being stated.

The age at death was under one month in 23 per cent (11 of each sex) and between one month 
and one year in 62 per cent (34 male $(4 \cdot 0 \pm 2.6 \mathrm{mo}$.) and 25 female $(5 \cdot 0 \pm 2.8 \mathrm{mo}$.) ): the remaining 13 were boys with ages ranging from 1 to 18 years, and 4 were girls aged between 1 and 3 years. There were 8 mongols, 6 male, 2 female.

Abbott (1936), in her series of 1000 cases, for the 50 in which she felt the V.S.D. to be the primary lesion, gives the mean age at death as $14 \frac{1}{2}$ years, the sex ratio being $M / F=1 / 1 \cdot 3$. In this series the ratio is $\mathrm{M} / \mathrm{F}=1 / 0 \cdot 8$.

Right ventricular (R.V.) hypertrophy, per se, was noted in 47 cases $(49 \%$ ); hypertrophy of both ventricles in $26(27 \%)$. In those children over the age of one month, 15 showed a patent ductus arteriosus (P.D.A.). A patent foramen ovale (P.F.O.) was seen in another 15, and an atrial septal defect (A.S.D.) in 5 children. Three showed both P.F.O. and P.D.A.

Morris (1957) describes the formation of the interventricular septum at some length, dividing the defect into three types. The first lies above the crista supraventricularis, the second lies below and behind, while the third affects the muscular septum proper. In this series there were 93 of the first two types and 2 of the third. Selzer (1949) in a review of collected cases found a defect in the muscular portion of the septum in 6 of 65 hearts, but this incidence is higher than usual.

More than half (55 cases; 58\%) died from bronchopneumonia, 4 from lobar pneumonia, 5 from gastro-enteritis, 4 from beri-beri, 1 from subacute bacterial endocarditis, and 5 showed further grave congenital abnormalities. There were no major sex differences. The true incidence of subacute bacterial endocarditis as a complication is difficult to arrive at, as published figures vary so widely. In clinical series such as those of Muir and Brown (1934) and Wood et al. (1954) the incidence is in the order of one per cent. Post-mortem figures as high as $\mathbf{5 7}$ per cent (Gelfman and Levine, 1942) have been reported.

\section{Atrial Septal Defects}

To describe these defects the anatomical criteria suggested by Taussig (1947) have been followed.

Persistent Ostium Primum. There were 4 cases of persistent ostium primum, 2 male aged 3 days, and 2 female, one newborn and the other two months old. All four showed patency of the ductus arteriosus: two showed dilatation of the pulmonary artery also and one a V.S.D. also.

Persistent Ostium Secundum. There were 45 cases of atrial septal defect, 23 male and 22 female. Abbott (1936) found the mean age at death for this condition to be 29 years and Wood (1956) 23 years. The age at death of our cases is given below.

Under one month -38 per cent -5 male, 12 female
One month-1 year -51 per cent -17 male, 6 female $(3 \cdot 4 \pm 2 \cdot 1$ mo.)
Over 1 year $\quad-11$ per cent -1 male aged 31 yr., 4 female aged $1 \frac{1}{2}, 3,15$, and $36 \mathrm{yr}$.

The ductus arteriosus was patent in 22 cases. The R.V. was hypertrophied in $38(84 \%)$, and was noted to be dilated in a further five; no change was noted in the other two, who died at birth. Hypertrophy of the R.V. is to be expected with a left-to-right shunt of any size. It is noteworthy that no fewer than 10 of the 14 infants who died at the age of seven days or less showed marked R.V. hypertrophy, but it seems difficult to imagine that hypertrophy gross enough to merit the attention of the pathologist could appear in the course of one week or less, and the normal increased relative thickness of the R.V. at birth may have been mistaken for hypertrophy.

Bronchopneumonia was the commonest associated disease $(56 \%)$. There were two cases of duodenal atresia, several of gastro-enteritis, beri-beri, and severe anæmia with ankylostomiasis.

Lutembacher's Syndrome. There was only one case-a 28-year-old Tamil Indian woman. The heart weighed $550 \mathrm{~g}$. and showed gross hypertrophy and dilation of the right side. A button-hole type of mitral stenosis was present, the A.S.D. was $2.7 \mathrm{~cm}$. in diameter, and the pulmonary artery was dilated and atheromatous.

Nadas and Alimurung (1952), from post-mortem material, found the incidence to be 6 per cent. Wood (1956) in his clinical material found the incidence as low as 0.3 per cent. The low incidence in Singapore is not due to an absence of rheumatic heart disease (Muir, 1958). 


\section{Patent Ductus Arteriosus}

Various figures are quoted for the normal time of closure of the ductus arteriosus. Wood (1956) suggests six weeks, while Schnitker (1952) states that patency of the ductus may be considered a normal finding through the first year of life. In a survey of 200 consecutive unselected autopsies performed by the author on Chinese children under the age of one year the mean age of closure was found to be $16 \cdot 0 \pm 4 \cdot 1$ days. For the purposes of this paper the presence of a P.D.A. in a child under the age of one month was considered normal.

There were 47 cases of P.D.A., 19 male and 18 female cases (in all $78 \%$ ) died between the ages of one month and one year, the mean age at death being respectively $2.9 \pm 2.1 \mathrm{mo}$. and $3.4 \pm 2.3 \mathrm{mo}$. There were 5 males between the age of 1 year and 50 years, 5 females between 1 year and 24 years.

A P.F.O. was found in 40 per cent. There was R.V. hypertrophy in 22 , L.V. hypertrophy in 6, and hypertrophy of both chambers in 4 cases. There were 24 deaths from bronchopneumonia, 4 from gastro-enteritis, 5 from other infections, and 2 from beri-beri.

\section{CoARctation of the Aorta}

There were 19 cases of coarctation of the aorta, 10 male, 9 female. To describe them, the classification of Wood (1956) has been followed. 15 cases, 6 male and 9 female, whose ages ranged from 5 days to $4 \frac{1}{2}$ years showed coarctation at the isthmus, i.e. between the left subclavian artery and the site of the ductus arteriosus.

Of these, 9 showed a V.S.D., 1 an A.S.D. The ductus arteriosus was patent in 14, and partially closed in 1 case. One showed an active rheumatic carditis, another a small aneurysm of the ascending aorta, and another a similar swelling at the start of the innominate artery. This latter case showed areas of cystic medial necrosis, with small areas of degeneration and disruption of the elastic tissue, and dilated vascular channels penetrating into the media from the adventia: although there was no mention of any of the usual concomitant stigmata, such as arachnodactyly, this appearance is highly suggestive of the aortic lesions found in Marfan's syndrome (McKusick, 1955). All 10 showed right ventricular hypertrophy. The left ventricle was moderately hypertrophied in only two-findings in keeping with those of Wood (1956).

One girl, aged 1 year, showed a lower dorsal coarctation extending over $1.5 \mathrm{~cm}$. This appeared to be a true congenital coarctation.

Left ventricular fibro-elastosis was observed in only 2 cases: they had been described from this standpoint, with 15 others, elsewhere (La'Brooy, 1956). Despite the frequency of bicuspid aortic valve in other reported series-Abbott (1928), 24 per cent and Reifenstein et al. (1947), 42 per centthe only associated abnormality was the absence, in one boy, of the left kidney. Bronchopneumonia was found in six of the children.

The three adults were men, aged 32, 39, and 55 years. The first had a lower dorsal coarctation and died by cardiac tamponade after retrograde dissection of the ascending aorta. The second, whose coarctation was at the isthmus, died with a coronary thrombosis. The third, with a presubclavian coarctation, had also aortic stenosis.

\section{AORTIC STENosis}

There were 10 cases of aortic valve lesions, 7 male, 3 female. Three of the male cases were aged 11,18 , and 47 years: the remainder, both male and female, 3 days to 3 months.

There was only one case of subaortic stenosis occurring in a man aged 18 who died while cycling. The heart was grossly enlarged, weighing $730 \mathrm{~g}$., with both ventricles dilated and hypertrophied. There was a large patent ductus arteriosus. The aortic valves appeared normal, but both coronary ostia were very small. The anterior wall and apex of the heart showed a recent infarct, but no thrombus was demonstrated in the coronary vessels. As far as the author is aware this is a unique case.

The remaining cases all showed a valvular type of stenosis. The salient features in the 7 infants 
was not as might be expected, hypertrophy of the left ventricular wall, but rather hypertrophy and dilatation of the right ventricle due no doubt to the presence of a large P.D.A.

One boy, aged 3 days, showed transposition of the great vessels, a valvular stenosis of the transposed aorta, and fibrous atresia of the pulmonary artery: there were in addition a large P.D.A. and an 0.5-cm. V.S.D.

The boy, aged 11, had a hypoplastic aortic arch associated with a bicuspid valve. The other valves were normal, there being no histological evidence of rheumatic disease in the affected valve which had thick rolled edges. Although it is impossible to exclude a rheumatic process, such thickening may be due to a secondary process (Edwards, 1953: Linnel, 1945).

The remaining adult showed four cusps to the aortic valve, two being tightly fused together along the free edge causing a relative stenosis: the remaining two cusps showed numerous fenestrations. There was no thickening or calcification in any cusp. While again it is impossible to exclude a rheumatic process, it is thought that this lesion was congenital in origin.

All 7 infants died with an associated bronchopneumonia.

Many authors used to be of the opinion that sub-aortic stenosis was the more common congenital lesion (Taussig, 1947). Others have found a high incidence of the valvular type (Campbell and Kauntze, 1953; Kiloh, 1950). In this series, as 7 of the cases were under three months, a rheumatic cause for the stenosis can almost certainly be ruled out.

\section{Pulmonary Stenosis}

There were 33 cases of pulmonary stenosis, 20 male and 13 female. There were 6 deaths of babies under one week of age, and 4 over one year. For the remaining $23(70 \%)$ the mean age at death for the 9 girls was $5 \cdot 1 \pm 2.3$ months, and for the 12 boys, $3.8 \pm 1 \cdot 1$ months. The incidence of the various types of stenosis is to be found in Table I. There was no significant age difference between those with a partial and those with a complete stenosis.

TABLE I

The Various Types of Stenosis Found in 33 Cases of Pulmonary Stenosis

\begin{tabular}{|c|c|c|c|c|}
\hline Location & Male & Female & Total & Percentage \\
\hline Partial valvular & 7 & 7 & 14 & 42 \\
\hline Complete valvular & 10 & 4 & 14 & 42 \\
\hline Pulm-art. narrowed $\quad$. & 1 & 1 & 2 & 6 \\
\hline Infundibular $\quad \ldots \quad \ldots$ & 一 & 1 & 1 & 3 \\
\hline $\begin{array}{l}\text { Pulm-art. obliterated or } \\
\text { partially closed by } \\
\text { fibrous ridge just } \\
\text { above valve } . .\end{array}$ & 2 & - & 2 & 6 \\
\hline
\end{tabular}

In this series, it was possible to make out some vestiges of valve cusp structure, in ten $(71 \%)$ of those with a complete stenosis of the valve. In those with a partial stenosis the valve cusps were distinguishable in all but one, most of the cusps showing moderate thickening.

The single case of infundibular stenosis was of the first type of Lev (1953) where there is a fibrotic band at the line of junction of the conus and the sinus. This produces a stenosis or atresia of the orifice of the conus and a large infundibular chamber. Kjellberg et al. (1955) classify this lesion in a manner that facilitates angiographic diagnosis according to the course of the bands of the crista supraventricularis.

Two cases in this series showed supravalvular stenosis. In one the artery was completely obliterated for $0.5 \mathrm{~cm}$. about $1.0 \mathrm{~cm}$. distal to apparently normal pulmonary valves. The second 
was like that described by Kjellberg et al. (1955) with a shelf-like rigid septum $1.0 \mathrm{~cm}$. above the valve which appeared normal.

There was some form of intracardiac shunt in $29(88 \%)$. A P.D.A. was found in 7, an A.S.D. and P.D.A. in 5, a P.F.O. and P.D.A. in 8, a P.F.O. in 6, an A.S.D. in 2, and a V.S.D. in one case. Ten children died with an associated bronchopneumonia and two with gastro-enteritis.

\section{The Tetralogy of Fallot}

There were 42 cases of Fallot's tetralogy, 19 male (45\%) and 23 female $(55 \%)$. Fifty-three per cent of the male, and 48 per cent of the female cases died before attaining the age of one year; 85 per cent of the male and 83 per cent of the female cases had died before the tenth year.

As the borderline between the tetralogy and pulmonary stenosis with a normal aortic root can be rather indefinite, only those specimens that showed clear dextroposition of the aorta are included. This, however, is an academic point here, as there was but one case of pulmonary stenosis with a ventricular septal defect. According to Taussig (1947), Fallot in his original paper of 1888 described both cases of pulmonary atresia and stenosis, whereas lately cases of atresia have been described separately. Four such cases with atresia were found in this series. All died before the age of 11 months. In one the pulmonary artery failed to communicate with the right ventricular cavity, ending blindly in the muscle, and showing no vestige of valvular tissue; in another there was atresia of the pulmonary artery. In all four the ductus arteriosus was patent, supplying the lungs with oxygenated blood. This particular lesion is well illustrated by Edwards et al. (1953). Kjellberg et al. (1955) found four such cases of atresia in their 38 cases of Fallot's tetralogy.

Table II shows, by sex, the various types of stenosis found in 42 cases of Fallot's tetralogy. From time to time widely different figures for the distribution of the various types of stenosis have been recorded. Baffes et al. (1953) in a series of 42 children, most of whom were under three years of age, found infundibular stenosis or atresia in every case: nine showed both valvular and infundibular

TABLE II

The Various Types of Stenosis Found in 42 Cases of Fallot's Tetralogy

\begin{tabular}{|c|c|c|c|c|c|}
\hline Lesion & $\begin{array}{l}\text { Mean age } \\
\text { at death }\end{array}$ & Male & Female & Total & Percentage \\
\hline $\begin{array}{ll}\text { Valvular stenosis } & \ldots \\
\text { Infundibular stenosis } & \ldots \\
\text { Valvular \& Infundibular } \\
\text { Atresia of valve } & \ldots \\
\text { Atresia of P.A. } & \ldots \\
\text { Type not stated } & \ldots\end{array}$ & $\begin{array}{l}4.4 \mathrm{yr} . \\
6.0 \mathrm{yr} . \\
4 \overline{\mathrm{mo}} \\
- \\
-\end{array}$ & $\begin{array}{r}12 \\
4 \\
1 \\
1 \\
1\end{array}$ & $\begin{array}{r}11 \\
8 \\
1 \\
3 \\
- \\
-\end{array}$ & $\begin{array}{r}23 \\
12 \\
2 \\
3 \\
1 \\
1\end{array}$ & $\begin{array}{r}55 \\
29 \\
5 \\
7 \\
2 \\
2\end{array}$ \\
\hline Total .. & - & 19 & 23 & 42 & 100 \\
\hline
\end{tabular}

stenosis, but none had valvular stenosis alone. Brinton and Campbell (1953) in a series with a different age distribution found isolated valvular stenosis in 8 per cent of their autopsy material. In this series the incidence is very much higher.

A bicuspid pulmonary valve was found in 5 cases $(12 \%)$; four were female; and four were associated with an infundibular type of stenosis. None of these showed any evidence of a bacterial endocarditis, in keeping with the findings of Gelfman and Levine (1942).

One woman, of uncertain age, died shortly after delivery of a boy, weighing $2 \mathrm{lb}$.: in addition to the tetralogy there was a right-sided aorta. Right-sided aorta was noted in 2 others, an incidence of 7 per cent. This figure is lower than in other series-20 per cent being not uncommon (Edwards et al., 1953; Donzelot and D'Allaines, 1954): Kjellberg et al. (1955) found it in 11 per cent of 38 cases. Several other major arterial anomalies were present (see p. 250). Complete atresia of the left pulmonary veins was seen in a girl who survived for 6 weeks: the veins were represented by a thin fibrous cord. 
Fallot's tetralogy is often associated with abscess formation (Gates et al., 1947) principally in the brain. In this series there were 5 instances of brain abscess, all on the right side, one cerebellar, the remainder parietal. A pneumococcus was grown from one, and $E$. coli from two others: Maronde (1950) found the commonest organism was the streptococcus. Wechsler and Kaplan (1940), in a review, found such abscesses to be more common on the right than on the left, but this was not supported by Campbell (1957).

Multiple kidney abscesses were found in one girl aged 6 weeks, and a large right lower lobe solitary lung abscess in a boy aged 9 years. Subacute bacterial endocarditis was seen in 3 persons aged between 11 and 40 years. There was one case of right superior cerebral vein thrombosis. 17 per cent of cases died with bronchopneumonia and 14 per cent with pathological evidence of chronic heart failure: the remainder died from miscellaneous causes. There was no case of tuberculosis, and but one mongol in this group.

Atresia of the Pulmonary Artery. Pulmonary artery atresia was seen in 4 cases ( 2 male, 2 female), the ages of which ranged from one week to seven months.

The pulmonary artery was represented by a cord-like structure as far as the bifurcation. All 4 showed a large P.D.A. which supplied blood to the lungs via the right and left branch of the pulmonary artery. These vessels were noted as being rather smaller than usual. A V.S.D. was noted in 3 cases.

\section{Tricuspid VALVE Lesions}

There were 8 cases of congenital disease of the tricuspid valve, 2 male, 6 female. One girl, aged 8 months had tricuspid stenosis. Both tricuspid and pulmonary valves showed severe stenosis, admitting a probe with difficulty. The wall of the right ventricle was thickened and the chamber small in size. The right atrium was slightly larger than normal, and there was a small A.S.D., $0.4 \mathrm{~cm}$. in diameter. The pulmonary artery was hypoplastic and the bronchial arteries much enlarged.

There were 3 cases of tricuspid atresia. In the first, a boy aged 2 years, the R.V. was very small, the pulmonary artery atretic, and the ductus arteriosus closed: there was a moderate sized A.S.D. This case corresponds to type 1a of Edwards and Burchell (1949). The second, a boy aged 3 months, was the same with, in addition, a V.S.D. The third, an Indian girl aged 5 years, was in essence the same, the right ventricle showing an unusual anomaly. In addition to being small and thick-walled, it was divided at its mid-point by a muscular septum at the centre of which was a small $2 \mathrm{~mm}$. orifice: the upper chamber so formed communicated with the left ventricle by means of a 0.4-cm. V.S.D. and with a hypoplastic pulmonary artery by means of a bicuspid pulmonary valve. Taussig (1936) has stressed the underdevelopment of the right ventricle.

Of the 37 reported cases of tricuspid atresia collected by Sommers and Johnson (1951), 28 had died within the first year, 3 within the second, and 6 between the ages of 2 and 5 . The average age of the 13 cases of Wood (1956) was 9.4 years.

There were 4 cases of Ebstein's anomaly, all female, one aged 10 months, the others 14 years. The sex ratio is usually equal (Wood, 1956). The morbid picture was quite typical, the anterior cusps retaining some attachment to the annulus fibrosus, and the posterior losing its connection entirely and being attached to the R.V. wall. All cases showed dilatation of right ventricle and atrium, the valve ring being described as dilated in all four. All showed enlargement of the spleen and a P.F.O. In the three older girls there was early cardiac cirrhosis, and a large pericardial effusion.

\section{Transposition of the GREat VesSels}

There were 21 cases of transposition of the great vessels, 14 male and 7 female. The mean age at death was $2 \frac{1}{2}$ months, the eldest surviving to the 18 th month with the aid of a P.D.A., a P.F.O., and a V.S.D. $1.0 \mathrm{~cm}$. in diameter. Fourteen showed hypertrophy and dilatation of the right ventricle; a P.D.A. was present in 14; a V.S.D. in 8; an A.S.D. in 2; and a P.F.O. in 7. 
There were several associated anomalies. (1) The aorta did not give rise to the left subclavian artery which arose instead from the left main pulmonary artery at its point of origin. (2) There was complete obliteration of the pulmonary trunk as far as the bifurcation, the lungs being supplied by a large P.D.A. from the aorta (which arose of course from the right ventricle). (3) Both atrioventricular valves were bicuspid in one case. (4) There was an infantile type of coarctation of the transposed aorta associated with a congenital mitral stenosis and a small left ventricle. (5) The viscera were transposed in two cases.

In all cases the coronary arteries arose normally behind the transposed aorta. Bronchopneumonia was found in seven $(33 \%)$. The mean age at death for Wood's (1956) cases was 13 years, the sex incidence being equal. The mean age at death in Abbott's (1936) cases was 6 months for those in whom the ventricular septum was intact, and $2 \frac{3}{4}$ years for those with a V.S.D. In this series the presence of a V.S.D. seemed to have no effect on prognosis, contrary to what is generally accepted (Schnitker, 1952; Hanlon and Blalock, 1948).

\section{EISENMENGER's COMPLEX}

Eisenmenger's complex is ventricular septal defect with a reversed (i.e. right-to-left) shunt, in the absence of pulmonary stenosis. It has been the habit in the past to attribute this reversed shunt to dextro-position of the aorta. As Wood (1956) points out, Eisenmenger himself was not responsible for this mistake and thought that any apparent over-riding was the result, and not the cause, of the altered blood flow. In a paper such as this, based entirely on morbid anatomical findings, it seemed best to describe those hearts with ventricular septal defect, over-riding of the aorta, and right ventricular hypertrophy as Eisenmenger's complex. Pathologically it is often difficult to differentiate between ventricular septal defect with a normal aortic root and an Eisenmenger complex with minimal displacement of the aorta. In consequence the number of cases of the complex in any purely morbid series may be rather lower than it ought to be.

There were 16 cases of Eisenmenger's complex, 11 male $(69 \%)$ and 5 female $(31 \%)$. Of the former, 2 died in the first 3 days, and the other 9 between the 2 nd and 16 th months. Of the female cases, 1 died at birth, and the other 4 between the 2 nd and 7 th month. For this series, for those surviving for more than a week the mean age at death for both sexes was $4 \cdot 8 \pm 4 \cdot 0$ months.

Degrees of right ventricular hypertrophy ranging from moderate to gross were found in 11 of our cases $(69 \%)$. Ten $(63 \%)$ of the cases died with an associated bronchopneumonia, 1 with lobar pneumonia, 1 with purulent meningitis. Another died with beri-beri, and one, aged 16 months, weighed $8 \mathrm{lb}$. at death. There were several other developmental abnormalities within this group: 1 mongol, 1 with complete situs inversus, 1 with isolated dextrocardia, and 2 with anomalies of the digits. There were 2 cases with a bicuspid pulmonary valve, 1 male, and 1 female.

\section{TRUNCUS ARTERIOSUS}

There were 12 cases of truncus arteriosus communis persistens, 5 male and 7 female. The average age at death was $4 \cdot 3 \pm 2.5$ months, three dying under the age of 1 month, the oldest being 10 months at death. In Abbott's (1936) series the average age at death was 4 years. All the cases seen were of the true form, i.e. the pulmonary arteries arising from the common trunk carried blood to the lungs. A more detailed anatomical classification is given by Collet and Edwards (1949). As is not uncommon (Schnitker, 1952), there were 5 cases in which there was complete absence of the interventricular septum, producing a cor triloculare biatriatum; the remaining 7 showed a V.S.D. An A.S.D. was noted in two cases, mitral atresia in one, absence of the spleen in one, dextrocardia in two, anomalies of the coronary vessels in two, and twin superior venæ cavæ in one case.

In another, the truncus descended along the right vertebral border giving off, $1.5 \mathrm{~cm}$. distal to the arch, a left subclavian artery which passed posterior to the œsophagus to gain the left arm. Just 
distal to the origin of this vessel the pulmonary arteries arose, the left passing anterior to the œsophagus and trachea and posterior to the ascending truncus.

Bronchopneumonia was found in six cases and beri-beri in one.

\section{ANOMALIES OF the GREAT VesSEls}

There were 7 cases, of which 5 were female. Six died under 2 weeks of age. The following anomalies were encountered.

(1) The pulmonary artery divided just above the valve cusps, but was otherwise normal. The right ventricle showed an unexplained massive hypertrophy, and the upper lobe of the right lung showed numerous congenital cysts.

(2) The pulmonary artery was enlarged, and continued, after giving off its branches to the lungs, as the aortic arch, giving off the great vessels of the neck. It then continued as the thoracic and abdominal aorta. The aorta, which arose normally from the left ventricle, joined the pulmonary artery posteriorly just distal to its pulmonary branches. There was also an associated duodenal stenosis.

(3) The pulmonary artery arose behind, and to the right of the aorta, i.e. corrected transposition of the great vessels.

(4) The left subclavian artery arose from the pulmonary artery. There was a V.S.D., right ventricular hypertrophy, and a right-sided aorta.

(5) There were two instances of congenital interruption of the aortic arch. An enlarged pulmonary artery continued as the descending aorta, through the ductus arteriosus, after giving off its branches to the lungs: a rather small aorta arose normally from the left ventricle to supply the head and neck, terminating in the left subclavian artery. In neither was there a fibrous strand between this vessel and the thoracic aorta. Both showed high interventricular septal defects. Embryologically the lesion represents an abnormal disappearance of the 4th aortic arch which would normally form that part of the aorta between the origin of the left common carotid artery and the aortic end of the ductus arteriosus. Foley (1958) was able to trace only 8 cases of this particular anomaly, her own included.

(7) This presented a variation of the above lesion. Two parallel vessels arose from the leftsided ventricle in a transposed heart. That on the left gave rise to a left common carotid, a right innominate, and a right subclavian artery, while that on the right supplied the lungs, continuing through a widely patent ductus arteriosus as a right-sided aorta. From this latter vessel the left subclavian artery arose. There was no communication between the two systems. The right-sided ventricle, which was very small, had no exit.

Associated with Fallot's tetralogy two major arterial anomalies were encountered. In one, the left subclavian and common carotid arteries arose from a common stem, and at the bifurcation of the $1.0 \mathrm{~cm}$. long common vessel there was a large P.D.A., which joined the pulmonary artery at its bifurcation. In the other, the pulmonary artery continued, after supplying the lungs, via the ductus arteriosus and gave rise to a right subclavian and right and left common carotid arteries: the aorta gave off a left subclavian branch before continuing normally along the left vertebral border.

\section{Persistent Atrio-ventricularis Communis}

There were 12 cases, 6 male, 6 female. Seven died between the 1st and 6th months, the mean age being 4.0 \pm 0.8 months and the oldest 14 months at death. Abbott (1936) found in her series, the average age at death to be 1.5 years, with a maximum of 4.75 years. In 55 cases reviewed by Rogers and Edwards (1948) over half died in the first year of life, and only 5 survived to the age of 30.

Partial aortic ring stenosis with aortic hypoplasia was found in one case: pulmonary valve stenosis with a right-sided aorta in another; situs inversus with absence of the spleen in a third case, and there was one case of unilateral absence of the radius.

Bronchopneumonia accounted for 7, and gastro-enteritis for 2 deaths. Although Moragues (1943) found mongolism in half his cases, only one of this group was considered to be a mongol. 


\section{COR BILOcUlare}

There were 8 cases of cor biloculare, 6 male, with ages ranging from newborn to two months, and 2 female, both aged two days. The common atrio-ventricular valve was attached to the right of the cardiac apex in all 8 cases. Generally it had 4 leaflets, although one was bicuspid. A truncus arteriosus was present in five cases, a persistent left superior vena cava in two, and a right-sided aorta in three.

There were three associated coronary artery anomalies, which will be reported elsewhere. There was complete transposition of the organs in three cases, abdominal transposition with a left-sided aorta in one, and splenic agenesis, associated with transposition of stomach, pancreas and a central mesentery, in two cases. The cases of splenic agenesis, with several others, have been reported elsewhere (Muir, 1959). Three of the infants were noted to have bronchopneumonia.

Brown (1950) has divided cor biloculare into two main groups, one in which there is rudimentary septum formation (in other words persistent ostium atrio-ventriculare commune) and the complete form with no septa. This latter group he further divides into two classes depending on whether there is division of the truncus arteriosus, or whether it persists. In those cases with both aorta and pulmonary artery, Brown (1950) found these vessels to be invariably transposed. The author failed to confirm this observation in his cases. Anomalies of venous return are very common in this condition, particularly persistence of the left superior vena cava (Kugel, 1932).

\section{CoR Triloculare Biatriatum}

There were 8 cases of this anomaly; 4 of either sex, with ages ranging from newborn to eight months. Schnitker (1952) divides this lesion into two groups. (1) In the first or true form, there is complete arrest of the development of the interventricular septum, with both atrio-ventricular orifices opening into a common ventricle. From this common chamber arise the aorta and pulmonary artery, or often a common arterial trunk. Very frequently these great vessels are transposed. (2) In a larger group the heart has four chambers, consisting of the two atria, a single common ventricle, and a small rudimentary chamber usually situated in the region of the pulmonary conus of the right ventricle. This cavity communicates with the larger being separated from it by a muscular ridge. One or other or both of the great vessels may arise from this small chamber.

In this series there were 3 cases of the true form ( 2 of which had transposed great vessels) and 1 of the "common" type, with a right-sided aorta. There were a further 4 cases that did not fall into either of these categories as they showed atresia of the mitral valve. Although some would discuss these cases separately, others regard them as having a functional cor triloculare biatriatum. To the author they seem to be but a further complication of the basic lesion.

Cor Triloculare Biventriculare. There were 4 cases of this rare condition, one male aged 9 days, and three female, one newborn and the others aged 2 months. One showed an associated mitral valve atresia, the valve opening being represented by a dimple, as well as a large V.S.D.

\section{Miscellaneous}

There were 5 cases of major anomaly of great veins, and 4 of coronary vessels, in addition to those associated with other defects. In view of their complexity they will be described elsewhere.

There were 3 cases of idiopathic cardiomegaly, two boys aged 1 and 2 years, and one girl aged 5 years, whose hearts weighed 90,115 , and 235 g. respectively. Comparable normal values (Coppoletta and Wolbach, 1933) would be 45,56 , and $85 \mathrm{~g}$.

There was one case of idiopathic dilatation of the pulmonary artery in a girl of 3 months; one case of cor triatriatum in a boy of 3 months; and one of rupture of an aneurysm of the right posterior aortic sinus in a girl of 14 years. 


\section{Discussion}

Little has been written on congenital heart disease in Asia. In 1936 Karcher found 6 cases, of unspecified type, in 282 (i.e. $2 \%$ ) cardiac cases seen in women and children at Canton. Other papers, such as that of Fu P'ei-Pin et al. (1958), have been confined to a discussion of the surgical aspects of individual lesions.

Hadley et al. (1958) in a series of 2000 necropsies at Vellore, S. India, found $25(1.3 \%)$ with congenital heart disease, representing 15 per cent of the cardiac deaths. This series is of some relevance to Singapore, as many of the Indians here originated from this part of India. We have failed to find any paper on the incidence of congenital heart disease in South East Asia, and this communication presents, it is believed, for the first time such data for persons of Chinese race. The paucity of published work is not difficult to understand as hitherto the attention of workers has been directed to the treatment of the tropical diseases: it is only of late that the magnitude of the residuum, especially tuberculosis and heart disease, has become manifest.

It has been shown that in Singapore congenital heart disease accounts for 2.2 per cent of all necropsies, and for 16.0 per cent of all cardiac deaths (Muir, 1958). In 1958 congenital heart disease accounted for 8.4 per cent of the 1077 necropsies on children under the age of 10 years, yielding pride of place only to bronchopneumonia and gastro-enteritis, and it seems likely that its relative place on the mortality table will rise rather than fall.

In the decade under consideration just over 400,000 Chinese children were born in Singapore. As some 380 with congenital heart disease under the age of 10 years came to necropsy in the same period, the minimum absolute incidence in Singapore is about 1 per 1000 births. Carlgren (1959) found that the numbers dying from congenital heart disease in Gothenburg corresponded to $2 \cdot 5$ per 1000 live births.

The stillbirth rate in Singapore is low (in 1956, $14 \cdot 7$ per 1000). In this series there were 14 stillbirths $(3.4 \%)$, and as during the same period some 8501 children were stillborn, the minimum incidence for congenital heart disease in the stillborn is therefore $1 \cdot 7$ per 1000 . This figure is somewhat higher than the figure of 1 per 1000 given by MacMahon et al (1953), and is almost certainly too low as about half the stillbirths are not born in hospital.

The incidence of the different types of congenital heart disease, shown in Table III, seems much the same as in other parts of the world so there is no point in discussing the minor differences.

In this series 19 per cent of the children died in the first week, 31 per cent in the first month, 72 per cent in the first six months, and 83 per cent in the first year. Corresponding figures for Gothenberg are 35, 56, 58, and 81 per cent. Gibson (1956) surveying the findings in 200 necropsies of congenital heart disease seen at Great Ormond St., London, found that 22 per cent died in the first month, 62 per cent in the first six months, and 84 per cent in the first two years. These figures are remarkably similar and would suggest that it is the heart lesion, rather than environmental factors, that primarily determines the time of demise. Although the feeding of infants on condensed milk and, as they grow older, on polished rice and the high incidence of gastro-enteritis and bronchopneumonia must have some effect on mortality, it seems to be very much less than the author had anticipated at the outset. The figures given above are at variance with those of Abbott (1936) which are probably not truly representative, being collected from reported cases.

The sex ratio in this series $M / F=52 / 48$ is much the same as in others-Carlgren (1959), 55/45; McMahon et al. (1953), 53/47; Gardiner and Keith (1951), 51/49. It will be noted that, when numbers warranted, the mean age at death, with standard deviation, has been given. Generally the boys died earlier, but not all the differences are statistically significant.

The incidence of mongolism, 4 per cent, is rather low when compared with the figures of Carlgren (1959; 13 per cent of his autopsied cases) but the clinical diagnosis of mongolism in Chinese is rather difficult. A comparable figure for Birmingham, on the other hand, was 6 per cent.

\section{SUMMARY AND CONCLUSIONS}

The principal morbid features of the 411 cases of congenital heart disease seen in 19,415 con- 
TABLE III

Incidence of Different Types of Congenital Heart Disease in Singapore

\begin{tabular}{|c|c|c|c|c|c|c|c|c|c|c|c|c|c|}
\hline Author & . & .. & . & . & . & .. & $\begin{array}{c}\text { Muir } \\
(1959)\end{array}$ & $\begin{array}{c}\text { Muir } \\
(1959) \\
(b)\end{array}$ & $\begin{array}{l}\text { Ober } \\
\text { and } \\
\text { Moore } \\
(1954) \\
(c)\end{array}$ & $\begin{array}{c}\begin{array}{c}\text { Abbott } \\
(1936)\end{array} \\
(d)\end{array}$ & $\begin{array}{l}\text { Gibson } \\
(1956)\end{array}$ & $\begin{array}{l}\text { Dry } \\
\text { et al. } \\
(1948) \\
(f)\end{array}$ & $\begin{array}{c}\text { McMahon } \\
\text { et al. } \\
(1953) \\
(g)\end{array}$ \\
\hline \multirow{2}{*}{\multicolumn{2}{|c|}{ No. of Cases }} & . & . & . & .. & .. & 411 & 121 & 100 & 1,000 & 200 & 133 & 255 \\
\hline & & \multicolumn{4}{|c|}{ Lesions } & & & & & & & & \\
\hline V.S.D. & & . & .. & . & . & .. & $23 \cdot 1$ & $18 \cdot 1$ & $19 \cdot 0$ & $6 \cdot 2$ & $8 \cdot 5$ & $12 \cdot 0$ & $15 \cdot 3$ \\
\hline A.S.D. & & . & 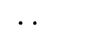 & . & . & .. & $11 \cdot 9$ & $16 \cdot 5$ & $6 \cdot 0$ & $3 \cdot 3$ & $10 \cdot 0$ & $20 \cdot 0$ & $8 \cdot 6$ \\
\hline P.F.O. & & . & . & . & .. & .. & - & - & - & $4 \cdot 0$ & - & - & $4 \cdot 3$ \\
\hline \multirow{2}{*}{\multicolumn{3}{|c|}{ Aortic Valve Stenosis }} & . & .. & .. & .. & $11 \cdot 4$ & - & - & $10 \cdot 5$ & $4 \cdot 5$ & $15 \cdot 0$ & $17 \cdot 6$ \\
\hline & & & . & .. & .. & .. & $2 \cdot 4$ & $4 \cdot 1$ & $2 \cdot 0$ & $3 \cdot 5$ & 2. & & 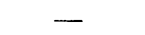 \\
\hline \multicolumn{3}{|c|}{ Coarctation of Aorta } & $\therefore$ & & .. & .. & $4 \cdot 6$ & $8 \cdot 3$ & $11 \cdot 0$ & 8 . & $4 \cdot 0$ & $12 \cdot 0$ & $10 \cdot 6$ \\
\hline \multirow{2}{*}{\multicolumn{3}{|c|}{$\begin{array}{l}\text { Pulmonary Stenosis (C) } \\
\text { Fallot's Tetralogy }\end{array}$}} & Closed & V.S.) & .. & .. & $8 \cdot 0$ & $7 \cdot 6$ & - & 3 . & $2 \cdot 0$ & & 1.6 \\
\hline & & & & .. & .. & .. & $10 \cdot 4$ & $7 \cdot 4$ & $4 \cdot 0$ & 8 . & $20 \cdot 5$ & $9 \cdot 0$ & $4 \cdot$ \\
\hline \multicolumn{3}{|c|}{ Pulmonary Atresia } & & . & .. & .. & 1.0 & $1 \cdot 7$ & 1.0 & $4 \cdot($ & - & & - \\
\hline \multicolumn{5}{|c|}{ Transposition of Great Vessels } & . & . & $5 \cdot 1$ & $11 \cdot 6$ & $27 \cdot 0$ & 4.9 & $15 \cdot 4$ & $7 \cdot 0$ & $14 \cdot 9$ \\
\hline \multicolumn{4}{|c|}{ Eisenmenger's Complex } & & .. & .. & 3.9 & $2 \cdot 5$ & - & 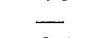 & 2 & & - \\
\hline & .. & $\therefore$ & .. & .. & 2.9 & $2 \cdot 5$ & $4 \cdot 0$ & $2 \cdot 1$ & 2 . & 2 & $6 \cdot 3$ \\
\hline \multirow{2}{*}{\multicolumn{3}{|c|}{ Common A-V Canal }} & . & . & .. & .. & $2 \cdot 9$ & $4 \cdot 1$ & - & - & 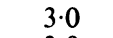 & 5 & - \\
\hline \multirow{2}{*}{\multicolumn{3}{|c|}{$\begin{array}{l}\text { Cor Biloculare .̈. } \\
\text { Cor Triloculare Biatria }\end{array}$}} & & . & .. & .. & 1.9 & $4 \cdot 1$ & $5 \cdot 0$ & 0.5 & $3 \cdot 0$ & 1 & $2 \cdot($ \\
\hline & & & Cor Triloculare Biatriatum & . & .. & .. & 1.9 & $2 \cdot 5$ & $6 \cdot 0$ & 1. & - & $4 \cdot 0$ & $2 \cdot($ \\
\hline \multicolumn{5}{|c|}{ Cor Triloculare Biventriculare } & $\because$ & .. & $1 \cdot 0$ & $1 \cdot 7$ & 1.0 & 0.5 & $1 \cdot 5$ & & - \\
\hline \multirow{2}{*}{\multicolumn{6}{|c|}{$\begin{array}{l}\text { Anom. of Great Vessels (including vein } \\
\text { Anom. of Coronary Arteries ... }\end{array}$}} & .. & $2 \cdot 9$ & $7 \cdot 4$ & 1.0 & 0.5 & - & $2 \cdot 0$ & - \\
\hline \multirow{2}{*}{\multicolumn{6}{|c|}{ Lesions of Tricuspid Valve and Ebsteein }} & .. & $1 \cdot 0$ & - & - & $1 \cdot 0$ & - & 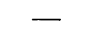 & $4 \cdot 3$ \\
\hline & & & & & & .. & $2 \cdot 0$ & - & - & 1.9 & - & - & - \\
\hline \multirow{2}{*}{\multicolumn{3}{|c|}{$\begin{array}{l}\text { Fibroelastosis } \\
\text { Miscellaneous }\end{array}$}} & . & $\ldots$ & & $\ldots$ & - & - & 7.0 & - & $7 \cdot 5$ & - & - \\
\hline & & & .. & $\ldots$ & 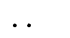 & $\ldots$ & $1 \cdot 3$ & - & 6.0 & $34 \cdot 5$ & 13.0 & $5 \cdot 0$ & 8.5 \\
\hline
\end{tabular}

Notes on the series in Table III.

(a) Muir (1959). Refers to the cases in this paper.

(b) Muir (1959). The 121 cases of congenital heart disease dying at birth or in the neonatal period are tabulated for easy comparison with those in (c).

(c) Ober and Moore (1955). In the period 1931-54, 1665 necropsies were carried out on stillborn infants, viable fotuses and infants dying in the neonatal period, at the Boston (U.S.A.) Lying-In Hospital. In this material 100 cases of congenital cardiac malformation were encountered.

(d) Abbott (1936). This series is drawn from the world literature and might be expected to have an undue preponderance of rarities. Figures quoted are for the numbers classified as primary lesion in her Chart $1.120(12 \%)$ in this series died in the first month of life.

(e) Gibson (1956). This paper describes the 200 cases of congenital heart disease coming to necropsy over 10 years at the Hospital for Sick Children, Great Ormond Street, London.

(f) Dry et al. (1948). 133 consecutive cases of congenital heart disease seen at necropsy at the Mayo Clinic.

(g) MacMahon et al. (1953). This column gives the incidence of lesions as seen at necropsy (236) and at operation for patent ductus arteriosus (19), in a series of 633 children with congenital heart disease traced from 194,418 births in Birmingham (U.K.).

secutive necropsies performed at the General Hospital, Singapore, in the decade 1948-57 are presented. They are found, with minor variations, to be, both in the nature of the lesions and in their relative incidence, much the same as in reported series from other parts of the world.

The proportion of Chinese $(97 \%)$ in the series is much higher than the proportion in the general population $(76 \%)$. An explanation for this discrepancy is adduced and there is no reason to think the incidence for congenital heart disease is higher among the Chinese than among other races.

The minimum mean incidence of congenital heart disease in the Chinese part of the Singapore populace is shown to be at least 1 per 1000 births, and for all stillbirths, 1.7 per 1000 .

A comparison of the cumulative mortality rate with other series shows a remarkable similarity, and suggests that even in tropical areas, the heart lesion primarily, rather than environmental factors, determines the age of death of the affected child. 
I wish to thank Professor R. Kirk for kind help, encouragement, and criticism. I am indebted to my colleagues for access to their post-mortem notes and material, to my wife for considerable help in extracting data from postmortem protocols, and to Mr. P. A. Samuel who typed the script.

\section{REFERENCES}

Abbott, Maude, E. (1928). Amer. Heart J., 3, 574.

(1936). Atlas of Congenital Cardiac Disease. Amer. Heart Association, New York.

Baffes, T. G., Johnson, F. R., Potts, W. J., and Gibson, S. (1953). Amer. Heart J., 46, 657.

Bedford, D. E., Papp, C., and Parkinson, J. (1941). Brit. Heart J., 3, 37.

Bonham-Carter, R. E. (1955). Personal communication to Wood (1956).

Brinton, W. D., and Campbell, M. (1953). Brit. Heart J., 15, 335.

Brown, J. W. (1950). Congenital Heart Disease. 2nd ed., p. 228. Staples Press, London.

Campbell, M. (1957). Lancet, 1, 111.

, and Kauntze, R. (1953). Brit. Heart J., 15, 179.

Carlgren, L.-E. (1959). Brit. Heart J., 21, 40.

Collett, R. W., and Edwards, J. E. (1949). Surg. Clin. North America, 29, 1245.

Coppoletta, J. M., and Wolbach, S. B. (1933). Amer. J. Path., 9, 55.

D'Autrebande, L., Marshall, W. R., and Meakins, J. C. (1930). J. clin. Invest., 8, 123.

Donzelot, E., and D'Allaines, F. R. (1954). Traité de Cardiopathies Cońgenitales. Masson et cie, Paris.

Dry, T. J., Parker, R. L., Rogers, H. M., Edwards, J. E., Burchell, H. B., Bulbulian, A. H. (1948). Congenital Anomalies of the Heart and Great Vessels. Charles C. Thomas, Springfield.

Edwards, J. E. (1953) in Pathology of the Heart and Great Vessels, edited by Gould, S. E. C. C. Thomas, Springfield.

-

_- Dry, T. J., Parker, R. L., Burchell, H. B., Wood, E. H., and Bulbulian, A. H. (1953). An Atlas of Congenital Anomalies of the Heart and Great Vessels. Charles C. Thomas, Springfield.

Foley, Bridget, V. (1958). Arch. Dis. Child., 33, 131.

Fu P'ei-Pin, Shen Yung-K'ang, Sung Hsiang-Ming, Shih Chi-Hsiang, and Lin Yen-Chan (1958). Chinese J. Surg., 6, 5.

Gardiner, J. H., and Keith, J. D. (1951). Pediatrics, 7, 713.

Gates, E. M., Rogers, H. M., and Edwards, J. E. (1947). Proc. Staff Meet. Mayo Clin., $22,401$.

Gelfman, R., and Levine, S. A. (1942). Amer. J. med. Sci., 204, 324.

Gibson, W. M. (1956). Great Ormond St. J., 11, 69.

Hadley, G. G., Gault, E. W., and Job., C. K. (1958). Amer. J. clin. Path., 29, 141.

Hanlon, C. R., and Blalock, A. (1948). Ann. Surg., 127, 385.

Karcher, J. F. (1936). Chinese med. J., 50, 705.

Kiloh, G. A. (1950). Brit. Heart J., 12, 33.

Kjellberg, S. R., Mannheimer, E., Rudhe, U., and Jonsson, B. (1955). Diagnosis of Congenital Heart Disease. The Year Book Publishers, Chicago.

Kugel, M. A. (1932). Amer. Heart J., 8, 280.

La'Brooy, E. B. (1956). Proc. Alumni Assoc., Malaya, 9, 77.

Lev, M. (1953). Autopsy Diagnosis of Congenitally Malformed Hearts. Charles C. Thomas, Springfield.

Linnel, F. (1945). Nord. Med., 28, 2555.

Maronde, R. F. (1950). Ann. intern, Med., 33, 602.

McKusick, V. A. (1955). Circulation, 11, 321.

MacMahon, B., McKeown, T., and Record, R. G. (1953). Brit. Heart J., 15, 121.

Moragues, V. (1943). Amer. Heart J., 25, 123.

Morris, E. W. T. (1957). Thorax, 12, 304.

Muir, C. S. (1958). Tran. Roy. Soc. Trop. Med. Hyg., 52, 446. (1959). Arch. Dis. Chldh. (In press).

Muir, D. C., and Brown, J. W. (1934). Arch. Dis. Child., 9, 27.

Nadas, A. S., and Alimurung, M. M. (1952). Amer. Heart J., 43, 691.

Ober, W. B., and Moore, T. E. (1955). New Eng. J. Med., 253, 271.

Reifenstein, G. H., Levine, S. A., and Gross, R. E. (1947). Amer. Heart J., 33, 146.

Rogers, H. M., and Edwards, J. E. (1948). Amer. Heart J., 36, 28.

Schnitker, M. (1952). Congenital Anomalies of the Heart and Great Vessels. Oxford University Press.

Selzer, A. (1949). Arch. intern, Med., 84, 798.

Sommers, S. C., and Johnson, J. M. (1951). Amer. Heart J., 41, 130.

Taussig, Helen B. (1936). Bull. Johns Hopk. Hosp., 59, 435.

(1947). Congenital Malformations of the Heart. The Commonwealth Fund, New York.

Wechsler, I. S., and Kaplan, A. (1940). Arch. intern. Med., 66, 1282.

Williams, A. W., and Simpkiss, M. J. (1958). In Diseases of Children in the Sub-Tropics and Tropics, edited by Trowell, H. C., and Jelliffe, D. B. Arnold, London.

Wood, P. (1956). Diseases of the Heart and Circulation. 2nd ed. Eyre and Spottiswoode, London.

, Magidson, O., and Wilson, P. A. O. (1954). Brit. Heart J., 16, 387. 